\title{
Community-based tourism: From a local to a global push
}

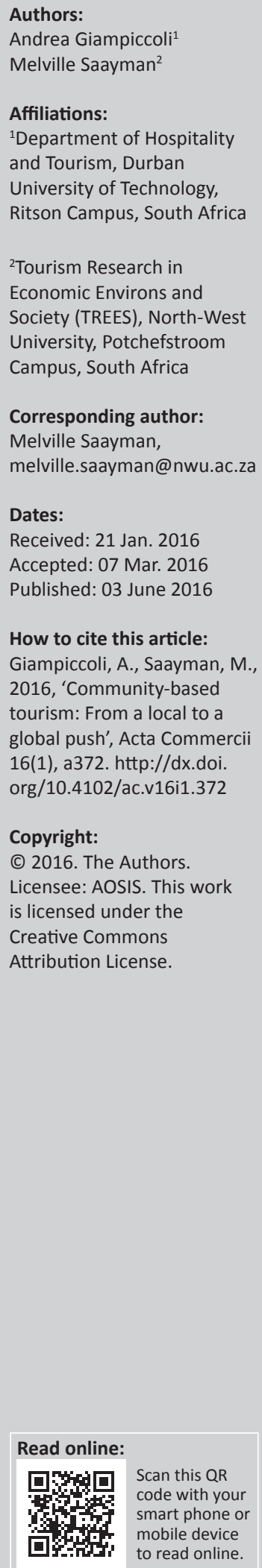

Orientation: World inequality is growing and tourism contributes to it; an alternative option is, therefore, needed towards a more just and redistributive approach to this industry.

Purpose: The aim is to propose that there is a need to advance the tourism sector to be more in line with community-based tourism (CBT) principles and practices.

Motivation of the study: The current tourism system exists within the more general neoliberal milieu. Alternative tourism forms are also often co-opted and circumscribed by a neoliberal framework. The issue is to a find a possible solution to advance a tourism development approach that enhances a decrease in inequalities.

Research design, approach and method: The article is a review paper.

Main findings: The results propose that the actual system of the tourism sector is in line with neoliberal milieu and does not militate against various inequalities (it, in fact, supports them). Therefore, a tourism development approach more based on CBT principles and practices is advocated.

Practical/managerial implication: A shift in the tourism development approach is proposed, reflecting the need to establish new policies and management structures that are fundamentally based on CBT principles and practices.

Contribution/value add: The article contributes to the literature related to the role of tourism in development, specifically debating matters related to the relationship between tourism, neoliberalism and alternative tourism. In addition, the article also deals with the debate on CBT.

\section{Introduction}

The potential of tourism in economic growth and social transformation strategies has been documented in the literature and recognised by international organisations (Pulido-Fernández \& López-Sánchez 2011:267). Despite different views about the conceptualisation of tourism as an industry and especially the largest global industry, virtually every tourism study currently published begins by highlighting the industry's spectacular growth over the past several decades (Fletcher 2011:444). The United Nations World Tourism Organisation (UNWTOa) (n.d.) accordingly proposes that over the decades, tourism has experienced continued growth and deepening diversification to become one of the fastest growing economic sectors in the world. Modern tourism is closely linked to development and encompasses a growing number of new destinations. These dynamics have turned tourism into a key driver for socio-economic progress.

Nevertheless, tourism growth does not necessarily work towards general poverty reduction and equality (Cole \& Morgan 2010). As such, the role of tourism in development has been doubted. Tourism's emphasis on its economic benefits has been countered by increasing concerns over the uneven nature of such economic development, and by serious questions about the environmental sustainability of the tourism industry and disquiet at the negative social and cultural impacts of tourism (Cole \& Morgan 2010:XVII). As a consequence of criticism to mass tourism various alternative tourism approaches developed, giving birth to alternative forms of tourism (Loizos Christou 2012:1). At the same time alternative tourism was used as a hope for proving consistency with natural, social and community values, as alternative tourism could have less negative effects on destination areas, environment and population, without diminishing positive economic effects (Loizos Christou 2012:1). Community-based tourism (CBT) is a type of tourism rooted in the alternative development approach (Giampiccoli 2015). A number of issues related to tourism globalisation, inequality and sustainability are therefore present. As proposed in relation to globalisation and sustainability, tourism will be one of the activities contributing towards 
intensifying the phenomenon of globalisation in the coming decades, but the contribution will not affect all geographical areas equally. In addition, tourism is facing a major, and global, challenge which is to ensure sustainability, with a forecasted number of global international arrivals reaching 1.6 billion in 2020 (Pulido-Fernández \& López-Sánchez 2011:268)

Based on the above this article's aim is to propose that there is a need to advance a tourism sector more in line with CBT principles and practices. A literature review will cover issues such as globalisation and alternative tourism forms related to many matters of the role of tourism in development. Matters associated to CBT are also presented. Thereafter a section indicating the way forward (with the background reasoning of the need of such a way forward) to internationalise CBT is advanced. This article is seen relevant, since recently (2015) it has been proposed that whilst scholars are investigating the contribution that tourism can make to economic growth and development since the 1970s, less attention has been paid to assessing whether tourism-induced growth and development contribute to the reduction of poverty and income inequality (Kinyondo \& Pelizzo 2015:64).

Whilst this article has these latter matters at its core, its aim is going beyond that, proposing a possible strategy to make tourism more equitable and sustainable as opposed to various negative effects of mass tourism. In this milieu, for example, the benefits of tourism and spill-overs to the poor depend on which model of tourism development is chosen. There are a number of examples, especially in developing countries, where big corporations protect the products they invest in, with the result that tourists see little of the country around them. The tourist spending remains in the hands of a few, with high leakages to major corporations in developed countries (Saayman, Rossouw \& Krugell 2012:463). This article can be seen as a modest contribution to the study of the role of tourism in development for a social justice and, whilst leaning from a social justice perspective, issues of sustainability should also be correlated as both social justice and sustainability challenge the neoliberal discourse (Cohen \& Cohen 2012:2186-2187). It has specifically been advanced that there is a growing concern in tourism studies with issues of social justice. An increasing number of researchers are engaging in advocacy-oriented research. They seek to move knowledge production in tourism away from neoliberal market ideologies. The field of tourism should be pushed towards a political agenda that 'promote[s] social justice and equality through tourism across the world' (Ateljevic, Hollinshead \& Ali 2009, in Cohen \& Cohen 2012:2186). At the same time, whilst concern about sustainability was initially directed to mass tourism, more recently alternative tourism forms such as ecotourism have also been under scrutiny (Cohen \& Cohen 2012:2187). This article will present the need to expand mainstream concepts and practices related to CBT as a way forward towards a more just, equitable and sustainable tourism industry. CBT will be intentioned in its initial understandings that are aimed at social justice, redistribution of resources, local control and ownership, sustainability, and empowerment.

\section{Literature review}

Together with its emergence and growth since the 1950s the tourism sector has become a more global phenomenon, progressively spreading into all regions of the world (PulidoFernández \& López-Sánchez 2011:268). It has been noted that as the scale of international tourism has grown, its geography has also evolved to reach a similar distribution between advanced and emerging economies (Scott \& Gössling 2015:270). However, an increase in tourism in order to have a positive effect on society requires a specific approach. The UNWTOa (n.d.) mentions that the contribution of tourism to economic well-being depends on the quality and the revenues of the tourism offered.

\section{Capitalism}

Capitalism is behind the tourism industry as stated by Harvey:

'Who invents the symbolic world that lies behind the branding of goods and places - a manipulative work that lies at the heart of contemporary advertising and the tourism industry - then becomes critical to the manipulation of human desires for monetary gain. It is, of course, the capitalists who take the monetary gain and who pay for the branding of their products.' (Harvey 2014:106)

The expansion of capitalism, however, does not seem to bring about a more just world. On the contrary, as suggested, the ultimate consequence of the political economy of global capitalism, its neoliberal ideology and the conflation of multiple crises unleashed has resulted in a massive increase in inequality across the world and within national political units. This gross effect correlates the growing intra-national and international inequalities (Maharajh 2011:10). Inequality of societies is likely to increase because of the unequal distribution of power, wealth, income, status and education. In general, global social stratification is more visible today than ever before. The gap between rich and poor, within both developed and developing nations is also growing (Zajda 2011:147). A document by the Organisation for Economic Co-operation and Development (OECD) (Cingano 2014:8) mentions that the disparity in the distribution of household incomes has been rising over the past three decades in a vast majority of OECD countries, and addressing these trends has moved to the top of the policy agenda in many countries as the world is more unequal today than at any point since World War II. However, there are clear signs that this situation cannot be sustained for much longer. Inequality has been jeopardising economic growth and poverty reduction (United Nations Development Programme [UNDP] 2013:1). Overview data can assist to understand the general inequality context; therefore, it has been expressed that globally the distribution of income remains uneven. In 2010, high-income countries - that 
accounted for only $16 \%$ of the world's population - were estimated to generate $55 \%$ of global income. Low-income countries created just above $1 \%$ of global income although they represent $72 \%$ of the global population. An average gross domestic product (GDP) per capita of \$2014.00 in subSaharan Africa in 2010 stood against regional GDPs per capita of \$27 640.00 in the European Union and \$41 399.00 in the USA (UN 2013:25).

Therefore it can be supported that a change in the development approach is needed, and to address inequality, countries need to generate inclusive growth. This means sharing the benefits of economic growth more equitably, in particular to increase the capabilities, opportunities and incomes of households and groups which are consistently on the margins of economic, social and political life. To close gaps in well-being, integrated development approaches are needed (Clark 2013:XI).

Importantly, it must be noted that evidence suggests that the income and prosperity gap between a small proportion of the world's population living mainly in the North and a large proportion living entirely in the South is a structural divide, not just a matter of a lag in the South's catch-up (Hunter Wade 2004:583). The restructuring of the tourism system can be seen as a possible contributor within its proportional value in the global milieu, towards a more equal society. This same issue was noted already in the late 1970s from a tourism study perspective where De Kadt (1979:38) proposed that no development strategy can hope to be successful without a restructuring of North-South economic relations.

Beyond this it has been proposed that the effect of tourism has also been towards inequality. Its expansion increases such negativities, where tourism has always been a site for and a contributor to social inequality; as tourism expands at a seemingly insatiable pace, the inequalities become increasingly evident and so too does the need for more complex and nuanced understandings of them (Cole \& Morgan 2010:XV). Other authors expressed in similar vein the doubt on the supposed positive link between tourism growth, development and poverty reduction (Gartner \& Cukier 2012:561; Kinyondo \& Pelizzo 2015; Saayman et al. 2012). As recent as 2014 it has been noted (McClendon 2014) in the case of the tourism boom of New Orleans, that the red-hot tourism industry has failed to create a solid middle class in a city riven by some of the worst income inequality in America. It is an uncomfortable truth for industry lobby groups used to touting tourism's massive impact on the local economy.

The role of tourism in inequality and the doubt on poverty reduction can be linked to the role of tourism in capitalist expansion; therefore, the current globalisation process. This might be viewed as one of the important means by which the capitalist world economy has sought to sustain itself in the post-war era. If sustainable tourism has become the dominant paradigm within the global tourism industry as a whole, then this may be partly because of the need to sustain capitalism as well. Tourism is, indeed, one of the few novel capitalist industries to appear (Fletcher 2011:458).

Lefebvre (2002:325) already mentioned in 1974 that tourism as one of the new sectors that contribute, through its expansion, to the survival of capitalism. Other authors (Bianchi 2009, 2010; Duffy 2014; Fletcher 2011; Giampiccoli 2007; Mowforth, Charlton \& Munt 2008:24; Schilcher 2007:63) follow similar lines indicating the role of tourism in capitalism expansion. The role of tourism within the international cooperation framework can also be seen as a strategy of capitalist penetration in new areas (Schilcher 2007:63). Therefore, tourism expansion as a way of capitalist survival may constitute one of the significant dynamics by means of which capitalism sustains itself in the present era (Fletcher 2011:446).

\section{Alternative tourism}

Expansion is both geographical and related to 'things' such as developing new 'tourist' services and opening up new territories for tourism development (Bianchi 2009:495, 2010:24). Different forms of alternative tourism have been judged differently. Various 'alternative' approaches to tourism have been proposed, such as pro-poor tourism (PPT), responsible tourism (RT), fair trade tourism (FTT), and ecotourism within the neoliberal logic whilst CBT can be seen as an alternative (Giampiccoli, Saayman \& Jugmohan 2014). Higgins-Desbiolles (2008) follows a similar line but sees justice tourism as a possible tourism alternative model. For example, a specific difference between CBT and other forms of alternative tourism (PPT, RT and FFT) has been recognised in the suggestion that PPT, RT and FFT are based on voluntary, self-regulating frameworks to adhere to their set of principles. CBT is not a self-regulating voluntary process, as it is a form of tourism with its own characteristics, challenges, problems and potentials. CBT is not based on the voluntarism of the mainstream tourism sector, but is a form of tourism that starts from within the community. It is not the mainstream tourism sector going to the community, but the community itself that owns and manages the tourism process (Giampiccoli et al. 2014:1673). In general it has been proposed that whilst alternative tourism forms (ET, PPT, RT and FFT) are not congruent with their theoretically (and terminologically) proposed aim, they remain (and are constructed) within the neoliberal framework and are therefore not leading to a real alternative in tourism development. On the other hand, $\mathrm{CBT}^{\prime}$ 's origin and contextualisation (despite its intrinsic challenges and limitations - as any forms of tourism development) seem more in line with the alternative tourism approach and holistic community development (Giampiccoli et al. 2014:1674).

On the difference between PPT and CBT it has, for example, been indicated that whilst engaging mass tourism has been seen as the key challenge for PPT policy, most reported success has been achieved with smaller scale communitybased initiatives (Biddulph 2015:99); see also Saayman and Giampiccoli (2016) on the difference between PPT and CBT. 
However, not all alternative tourism is 'bad'; for example, in the case of ecotourism it has been proposed that not all ecotourism is necessarily the handmaiden of capitalist expansion, merely that the industry as a whole plays an instrumental role in this respect (Fletcher 2011:447). It is the structure of the tourism system itself that needs to be transformed.

Therefore, new solutions that break from current ideological and implementation patterns need to be envisaged and implemented to shift the current global framework towards a more just and equitable one. New approaches and plans need to be put in place. Not the United Nations World Tourism Organisation (UNWTO) nor the World Travel and Tourism Council (WTTC 2013:3) have articulated how the projected doubling of international tourism by 2030 (and potentially tripling by 2050) might be accommodated sustainably (Scott \& Gössling 2015:277). The future of tourism is not without question marks and unpredicted and risky situations. For tourism to remain a business as usual is risky (Scott \& Gössling 2015:276). Solutions and changes are needed and an alternative tourism approach such as CBT can be used as a tool for social justice, equity, redistribution of wealth and resources, and empowerment (Giampiccoli 2015). As such, CBT should promote self-reliance, self-planning and self-management, be transformative, redistributive, empowering, holistic, developmental, enhancing individual and community capacities, participatory, with opportunities for co-production, community decision making, job creation, control and involvement, the attainment of social justice and the remediation of both power and resources (Giampiccoli \& Mtapuri 2015:45).

Whilst CBT maintains characteristics associated with other forms of business, namely that it has to be economically viable, with proper accountability, a management system, appropriate decision making processes, and networking (Giampiccoli, Jugmohan \& Mtapuri 2015:1211), it possesses its intrinsic diversity in how these characteristics are managed (for what purpose and by whom). For example, profit in CBT ventures should be equally distributed and also contribute to local development, and the control of the CBT ventures should remain in the hands of CBT members. By the same token CBT requires a proper marketing strategy and a customer satisfaction focus (see Mtapuri, Giampiccoli \& Jugmohan 2015).

In future, tourism will remain important with its own opportunities and challenges that will shape its scope and scale at the global, regional and destination scales (Scott \& Gössling 2015:276). However, the goal is to make the future of tourism at global, regional and destination scales more just, equitable, and sustainable. In this context alternative options to the current neoliberal framework need to be recognised and advanced. There are in fact many alternatives available for explorations that possess vast potential to foster both alternative tourism and alternative globalisation (Higgins-Desbiolles 2008:359). One such option is CBT that should be understood as opposing neoliberal forces (Saayman \& Giampiccoli 2016).

\section{Research methods and design}

The article is a review paper, and an array of relevant journal articles and conferences papers were utilised. Specific handbook and government documents were also used to sustain arguments, alongside those mentioned.

\section{Results}

\section{Towards internationalisation/mainstreaming of CBT}

The above section proposes that changes are needed to favour a more just and equitable tourism sector (and society) and that the CBT approach can been proposed as a possible solution. Contemporary neoliberal globalisation tends to reshape CBT approach, as indicated by Giampiccoli and Mtapuri (2012:40) and Saayman and Giampiccoli (2016); they argued that contemporary CBT, as managed and organised within the neoliberal framework, jeopardises the CBT's possible contribution to holistic community development, by shifting the priority to neoliberal, private sector imperatives and, often, private, external investment prerogatives. Therefore, despite the suggestions that CBT has been coopted/reconfigured by neoliberalism (Giampiccoli \& Mtapuri 2012) it can assist in the shift of the tourism sector and society if taken with its initial aims and objectives. CBT as part of the alternative tourism approach must be understood in the general context to regain its original meaning. Instead, the origins of alternative tourism in the 1960s counterculture movement have largely been forgotten (Higgins-Desbiolles 2008:346). The same has been specifically noted for CBT; presented in the 1990s, 'CBT differs from general community development theory and process in that it does not have the transformative intent of community development and does not focus on community empowerment' (Beeton 2006:50). In relation to CBT it is mentioned that despite the terminology of 'communitybased' and 'local participation' community-based ecotourism (CBET) is actually a game for those controlling the globalisation process; moreover it has been suggested that these alternative tourism projects were certainly not problemfree. What is important to note is that they were genuinely owned and controlled by local people and their organisations without interference by government, business and international agencies (Pleumaron 2002). Therefore, it is important to realise that globalised CBET has little in common with earlier forms of community-based alternative tourism. The most important aspect is the change of ownership. Local people are no longer right-holders in projects, but have been degraded to 'stakeholders', ostensibly on equal footing with other stakeholders ranging from (inter-) governmental bodies and industry to a great number of brokers, operating at the international, national and local level (Pleumaron 2002).

In this context alternative tourism, in rejecting mass tourism, is a similar radical attempt to transform social relations and is 
therefore part of the larger movement; some proponents and contributors to the alternative tourism phenomenon hold a radical agenda not only to overturn an inequitable, unjust and unsustainable tourism system, but they envision such efforts as a catalyst for a more humanistic form of globalisation (Higgins-Desbiolles 2008:346). In this respect it has been argued that CBT concepts and practices should strongly and unconditionally continue to prioritise and be specifically related to (and holistically benefit) disadvantaged communities' members within a redistributive and social justice framework at global and local level; it should also spin off to all tourism sectors. CBT should work to localise the ownership and control of the tourism sector as a whole. Whilst CBT must be much more proportionally directed to offer a strong and decisive advantage to disadvantaged communities' members (vis-à-vis more powerful/wealthy groups of society) and must strongly and holistically decrease the inequality gap between various groups of society at various geographical levels, it should influence and circumscribe the whole tourism sector (and society) to enhance the local control of, and local benefit from, tourism (Saayman \& Giampiccoli 2016).

Therefore, within the alternative development approach CBT also presents a possible alternative option to mass/ conventional tourism (Giampiccoli 2015; López-Guzmán, Sánchez-Cañizares \& Pavón 2011:73). Various approaches to alternative tourism development have been proposed as a way to overcome problems related to mass tourism, of which one is the CBT (Ahmad et al. 2015:181). This raises the question whether a CBT approach implemented across the globe is actually benefitting communities (Ahmad et al. 2015:181). It has also been suggested that CBT still have potential, but proper implementation and understanding of CBT is needed to achieve this potential. CBT can bring many potential benefits to the economy, society and environment of communities; however, if it is not assessed, planned and managed effectively with the communities, it may also come with an undesirable cost to society and the environment (Asker et al. 2010:7). Moscardo (2008:173) advances that, whilst CBT and ecotourism have not on the whole been as effective or sustainable as promised, they still hold the greatest potential for many regions. Therefore it could be argued that true CBT has not been implemented.

What is necessary to improve these forms of tourism is a greater awareness of the need to enhance community capacity for their development. It is, therefore, fundamental to analyse how CBT is implemented and conceptualised because how these features are understood and managed can influence the outcome of the CBT itself (Saayman \& Giampiccoli 2016). At the same time proper institutional support and policies are needed and the understanding of CBT must go beyond the specific locality. As well as identifying the inward fit, tourism stakeholders need to look externally beyond the community to the broader local and national planning and policy contexts. CBT ventures are most likely to be appropriate to the circumstances and succeed where institutional structures provide enabling policies, linkages between organisations, and skills or technical assistance to CBT. Countries with national enabling CBT policy frameworks are more likely to be conducive to supporting effective and appropriate CBT operations (Asker et al. 2010:20). A more regional approach in CBT is seen as appropriate (for example, in an Asia-Pacific Economic Region [APEC] region) where it is highly imperative that the principles and mechanisms of CBT are mainstreamed. Against this background, this article will assist member economies in incorporating the CBT model as part of their formal development process (mainstreaming). By doing so, CBT will no longer be an alternative development model but a formal development tool (Hamzah \& Khalifah 2009:1).

In addition, Saayman and Giampiccoli (2016) advanced that whilst CBT usually is small scale but often seen, there is no preclusion to CBT development at a greater scale. We therefore propose that the need is to go beyond local, national and regional approach of CBT and to 'formalise' and 'mainstream' it at a global level and consequently through decentralisation at regional, national and local level; all geographical levels have to be involved and associated in this process. This internationalisation/mainstreaming process needs to go beyond specific locality of countries to allow CBT to be mainstreamed and 'formalised' as alternative tourism development that counteract tourism's neoliberal approach. This is necessary for various reasons, for example, defining first of all CBT itself.

The definition of CBT could be seen as a perfect topic to explore in relation to the need of its 'formalisation' at the various geographical levels. Problems related to the definition of CBT have been widely reported in the literature (see Boonratana 2010; Flacke-Neudorfer, Burns \& Novelli 2008:246; Kiss 2004:232; Kontogeorgopoulos, Churyen \& Duangsaeng 2014:108; Mayaka, Croy \& Mayson 2012; Ndlovu \& Rogerson 2003:125). Importantly, the judgement of success or failure can depend on the various interpretations of CBT. The question of success is, therefore, a controversial one and depends largely on one's perspective and expectations (Kontogeorgopoulos et al. 2014:107). CBT should be unified in its meaning and operational process (Boonratana 2010:289). Various CBT policies at national and local level are present, for example, in Namibia (Ministry of Environment and Tourism [MET] 1995), Jamaica (Ministry of Tourism and Entertainment [MTE] 2014), Myanmar (Ministry of Hotels and Tourism [MHT] 2013), South Africa's KwaZulu-Natal Province (KZNDED n.d.), and various CBT manuals/ handbook and CBT organisations exist around the world (see Giampiccoli et al. 2014; Giampiccoli \& Mtapuri 2015). In addition there are a number of proposed CBT standards at national or regional level available such as the CBT standard for Cambodia (Cambodia Community-based Ecotourism Network [CCBEN/SNV] 2009), the CBT standard handbook focusing on Thailand (Suansri, Yeejaw-haw \& Richards 2013), and the Association of Southeast Asian nations (ASEAN) CBT Standard (ASEAN 2014). To note that standard can also be detrimental to community if the community is not 
suffuciently prepared or cannot maintain the proposed standard (Suansri et al. 2013:8). It is, however, proposed here that external entities should also be involved in facilitating the community to achieve the standards; at the same time standards can still form a baseline to which each community can aspire. Moreover, specific categories of standards could be envisaged to allow more communities, also those with less resources and capacity, to meet the standards (any specific category/level of standards) and be involved in CBT. Therefore, standards could have their own 'grading' so that all CBT projects have the opportunity to follow the CBT standards and guidelines. Moreover, the standards and possible associated grading should include specific relationship with external actors to demonstrate the level of each CBT project in relation to external control and influence, therefore uncovering misuse of the term CBT by private entities or other actors.

International organisations involved in CBT, for example the UNWTO, have been supporting numerous events and projects aimed at the development of CBT activities, where the main attraction for tourists is to experience the traditional way of life of small communities and where the operations are controlled and managed by the small community itself (UNWTOb n.d.). In 2014 the United Nations Educational, Scientific and Cultural Organisation (UNESCO) was involved in CBT in Vietnam (UNESCO 2014). However, an international recognised standard or a specific dedicated agency does not seem present. In this context what has been written from a Thailand perspective can be illuminating and globalised in its meaning, as CBT recognition of levels of confusion, and gaps, at national and international are present in Thailand on matters related to CBT. It will require a better integrated, more strategic approach, based on closer cooperation between the government of Thailand, non-government organisations (NGOs), and academic and community organisations (Dhiradityakul \& Hummel 2013:13). A global approach to CBT mirroring the same need at local and national levels is, therefore, seen as necessary. Specific guidelines, understanding and standards related to all aspects of CBT should be envisaged and establish and 'formalise' at all geographical and institutional levels.

\section{Implications}

The establishment of an international body for CBT is, therefore, advanced and proposed to enhance CBT in all its aspects and in all geographical areas. Ideally, this new body should be officially recognised by the tourism sector at international level; however, it should not remain under its control. Therefore, whilst endorsement from international tourism organisations could be envisaged no legal link (that implies that the new CBT remains legally independent from any external entity) or other form of control should be exerted on international level. If endorsement is not forthcoming other forms of international recognition should be envisaged and advanced. The core matter is that for the new body full independency is required if it aims to advance and foster
CBT in its original understanding as an alternative approach to mass conventional tourism and dedicated to the empowerment of disadvantaged people, and social equity. Instead, international tourism organisations such as the UNWTO and the WTTC remain within a neoliberal context. Tourism is, therefore, a commercial sector that operates within a global neoliberal market economy (Chok, Macbeth \& Warren 2007:144). Neth, Ol Rith and Knerr (2008:4) note that tourism becomes an exemplar of the expansion of neoliberalism (corporate globalisation) where capital has free rein, highlighting the link between the growth of tourism, structural changes in the global economy and fundamental shifts in international relations. This approach has also been favoured by an organisation such as the African Development Bank (ADB), the World Bank and the International Monetary Fund (IMF), and by bilateral donors, which have made loans available in return for reforms that favour market-oriented growth. They play vital roles in shaping the economic environment for tourism investment and development in much of the world (Giampiccoli et al. 2014).

This specific tourism milieu is favoured by its alliance and collaboration; one explanation is that the richest travel and tourism corporations have established huge international alliances to jointly push their ideas and interests at all levels. It is also noteworthy that the UN-affiliated World Tourism Organisation (WTO) is the only inter-governmental organisation that allows membership by the private sector. According to a recent WTO statement, the members of its Business Council (WTOBC) have become more active and more vocal in the organisation's meetings and programmes (Pleumaron n.d.; see also Pleumaron 2003 for the role of privatisation of the corporate tourism system). This, for example, runs counter to local ownership and control of the tourism industry. Schilcher (2007:71) mentions, based on a case study from Fiji, that development strategies focusing on local ownership and control 'generally run counter to the nebulous of neoliberalism, as well as systematic constrains under economic globalisation'.

CBT needs to remain as an alternative to the state of affairs of the current tourism industry; the new CBT body should, for example, be completely independent from the UN system to avoid any possible co-option/absorption by the mainstream neoliberal ideology. Whilst the body could be endorsed by the UN system, its independency and modus operandi needs to remain separated from it. In addition, the new global CBT body should be developed through a grassroots approach by constructing it from the bottom up; a type of bottom up centralisation, where a central (national up to global) CBT body is formed from the local decentralised CBT organisation. Disadvantaged community members should form the spine (and owners) of the new body whereas other actors such as academics, civil activists and progressive policy makers could accompany and facilitate the various aspects of the newly established body. A similar example, but at national level, has been proposed by Giampiccoli et al. (2014) in South Africa where community members as owners, co-managers 
and beneficiaries of the CBT organisations, working together with academics (co-managers of the CBT organisation) and in dialogue and collaboration and possible support from government bodies, and possibly in an ad hoc partnership for project with NGOs and private sectors, could be a possible option to mirror from local to global level.

Two final issues are worth noting in relation to the internationalisation of CBT. Firstly, CBT can be perceived to have an inferior quality of products compared to mainstream tourism (Ndlovu, Nyakunu \& Auala 2011:39). The Government of Barbados' (2012:10) Green Paper on the Sustainable Development of Tourism noted that negative attitudes exist within the industry towards community tourism products which are often viewed with scepticism and regarded as inferior within the formal sector. This state of thinking must be challenged. In this context the education of tourists in relation to CBT should be proposed as one of the fundamental vehicles to change attitude and perception of CBT products and services. The new CBT body should certainly also be involved in such educational task.

Secondly, whilst an alternative tourism approach (with CBT within it) is generally seen as small scale (Asker et al. 2010:2) its scaling-up should be regarded as possible. In the end it is necessary to scale up CBT if enough changes in the tourism sectors are desired. Therefore, the scaling-up of CBT should be seen as leading a shift in the control of resources and decision making processes towards communities, and to work towards a global change. The scale level that CBT could - perhaps should - achieve is important when related to the general shift that CBT could contribute to the general rebalancing/redistribution of control, resources, knowledge, capacities and benefits of the tourism sector as a whole. CBT must not be seen as a small, somewhat marginal, tourism segment, but should strive to become the central/main tourism segment of the tourism industry in order to shift the control of the industry to local community members (Saayman \& Giampiccoli 2016).

In addition, a common definition is relevant to avoid that a specific entity takes advantage of the CBT term and image as a result of its (CBT) 'saint-like' nature; several parties use the term 'CBT' like others use the term 'ecotourism' as a marketing gimmick to attract consumers who are then made to believe that they are supporting a good cause - which is to travel responsibly (Kayat et al. 2015:224). Therefore, as proposed by Ellis and Sheridan (2014:4) there is a need to inform a model for best practice of CBT. This can serve to enhance the success and potential of CBT and, also, to avoid voluntary (or not) misinterpretation and misuse of the term of specific entity benefit. In this context CBT standards or guidelines should go beyond the rules for CBT ventures and projects and serve to protect the community; as suggested for the CBT standard in Thailand it is not considered to be a set of rules for the community to follow. On the contrary, providing that community members understand the goals of the standard and participate actively in the process of using the standard, a CBT standard should actually serve to clarify and protect community rights (Suansri et al. 2013:7). In this article the internationalisation of CBT is intended in both ways, firstly to protect disadvantaged community members and, at the same time, define and propose conceptual and practical standards for the implementation of CBT. The two aspects go together when proper standards (standards that must also protect disadvantaged community members) attached to CBT development are recognised and, therefore, possibly legally bounded through legislation and policies, that community members can increase the power relations vis-à-vis more powerful groups. In this context it is important to underline that CBT implementation needs proper monitoring and evaluation to ensure that policies and guidelines are strictly enforced (Roslinda 2013:63).

Various aspects of CBT definition, implementation process, and standards should be included. The internationalisation of CBT should holistically include all aspects and matters related to CBT so that specific guidelines are present; but at the same time these guidelines should remain flexible and graded to fit each specific local context and allow as many communities as possible that wish to be involved. The management of CBT standards or guidelines (or any other aspects) needs specific strategies. Therefore, bearing the Indonesian perspective in mind, but arguably applicable at various geographical levels, from global to local, it can be proposed that developing CBT needs a major effort. Firstly, a continuous dissemination of information on product standard to more CBT stakeholders needs to take place. Secondly, it is imperative to assist local communities in implementing it. Finally, it is important to disseminate and assist local and national governments to endorse these initiatives with legal documentation (Suhandi \& Simatupang 2013:56).

In this context the role of both local and national government (and multinational bodies) should be seen as fundamental in facilitating and implementing policies and projects related to CBT. Governments should be a main protagonist in facilitating CBT development. As suggested, different actors, alone or in unison, can play a facilitative role, and government is a key agent in all aspects of the facilitative process (Mtapuri \& Giampiccoli 2013:5). Therefore, the ASEAN experience seems an exemplar in demonstrating the need to internationalise CBT. For example, whilst several ASEAN countries have over 10 years' experience in developing CBT (e.g. Cambodia, Indonesia, People's Democratic Republic of Lao, the Philippines and Thailand) there has never been an ASEAN forum for academics, practitioners and supporting businesses and organisations to exchange experience and knowledge about CBT (Suansri 2013:3).

\section{Limitation and future research}

The main limitation of the study is that it is exclusively a review article and, whilst it has considered various aspects to 
be able to propose and put forward arguments, it would need additional research to further analyse the issues. In this context future research, both theoretical and empirical, investigating the need and strategies to shift tourism development at local and global level towards a more just and redistributive approach is to be welcomed and is proposed; it is necessary in the current state of growth of world inequality. Further research should use a more empirical approach to demonstrate how this shift can take place and what programmes and policies could enhance this change towards a CBT approach. For example, whilst it is proposed that governments should be the main actors to financially assist the establishment of the new CBT body, there is a need to investigate alternative funding strategies for the new CBT bodies that can take place outside the neoliberal milieu that requires, in return, reforms that favour market-oriented growth.

\section{Conclusion}

This article has proposed and advocated for the internationalisation and mainstreaming of CBT concepts and practices in order to shift the tourism industry towards a more just, equitable, and sustainably tourism sector. This shift should be specifically understood within the context pushing towards a social justice and sustainable perspective of the tourism sector. Whilst the shifts to CBT approach will not be a full panacea (especially in the short term) and could be promoted in stages the shifts towards CBT values of the tourism industry are recommended. This article advocates in favour of the establishment of an international body specifically related to all aspects of CBT. Whilst specific strategies to facilitate this shift could be further investigated and debated, this article introduces the debate by proposing an array of initial ideas on how to advance CBT globally.

An introduction and literature have presented various issues related to the need to shift the tourism sector towards a CBT approach, debating issues related to tourism and inequality, capitalism, and the role of international organisations. Background issues such as the possible exploitation of the term CBT in the present climate have been proposed as a justification to the need to internationalise CBT. The article has been a review article and its aim has been to propose that there is a need to advance a tourism sector more in line with CBT principles and practices.

The article's findings debated the intrinsic relationship between tourism and neoliberalism and its consequent management of the tourism industry towards an unequal and unjust impact of tourism in societies and environments. A new approach towards the whole tourism sector is proposed to make it more just and equitable. CBT's original concepts are regarded as a possible solution towards this aim. The need to internationalise/mainstream CBT concepts and practice have been advocated together with possible options on how to establish a CBT international body with decentralised 'branches'. The article contributes to the literature related to the role in tourism in development, specifically debating matters related to the relationship between tourism, neoliberalism and alternative tourism.

Whilst the above proposed international/local CBT bodies are advocated, specific operational and management issues and methods to establish them are open to debate in finding the best solution to favour CBT bodies alternative to neoliberalism and directed towards social justice and sustainability. However, the need for the establishment of a CBT body present at various geographical levels and rooted in the values, concepts and practices of CBT's original meaning and understanding and opposing neoliberal tourism for social justice and sustainability, is proposed and advocated.

\section{Acknowledgement}

The authors declare that they have no financial or personal relationship(s) that may have inappropriately influenced them in writing this article.

\section{Competing interests}

The authors declare that they have no financial or personal relationships which may have inappropriately influenced them in writing this article.

\section{Authors' contributions}

A.G. was project leader and conceptualised, initiated and wrote the first draft of the review article. M.S. worked on the first draft, making changes as well as improving the general flow of the paper in order to be publishable.

\section{References}

Ahmad, J.A., Azmi, A., Anuar, M.S. \& Mohd Ali Tan, Z., 2015, 'Comparative analysis of cost and benefits between international and domestic community-based tourism in Malaysia', in S.A. Jamal, S.M. Radzi, N. Sumarjan, C.T. Chik \& S.M.F. Bakhtiar (eds.), Innovation and best practice in hospitality and tourism research, hospitality and tourism 2015 proceedings, pp. 181-184, Malacca, Malaysia, 2-3 November 2015

Asker, S., Boronyak, L., Carrard, N. \& Paddon, M., 2010, Effective community based tourism: A best practice manual, APEC Tourism Working Group, Griffith University, QLD, Brisbane, Australia.

Association of Southeast Asian Nations (ASEAN), 2014, ASEAN community based tourism standard, Cambodian Ministry of Tourism, Phnom Penh.

Beeton, S., 2006, Community development through tourism, Landlinks Press, Collingwood.

Bianchi, R.V., 2009 'The "critical turn" in tourism studies: A radical critique', Tourism Geographies 11(4), 484-504. http://dx.doi.org/10.1080/14616680903262653

Bianchi, R.V., 2010, 'Tourism, capitalism and Marxist political economy', in J. Mosedale (ed.), Political economy of tourism. A critical perspective, pp. 17-37, Routledge, London.

Biddulph, R., 2015, 'Limits to mass tourism's effects in rural peripheries', Annals of Tourism Research 50, 98-112. http://dx.doi.org/10.1016/j.annals.2014.11.011

Boonratana, R., 2010, 'Community-based tourism in Thailand: The need and justification for an operational definition', Kasetsart Journal: Social Sciences 31 280-289.

Cambodia Community-based Ecotourism Network (CCBEN/SNV), 2009, Community based tourism standards in Cambodia, viewed 5 November 2015, from https:// ysrinfo.files.wordpress.com/2012/06/7_cbt-standards-in-cambodia.pdf

Chok, S., Macbeth, J. \& Warren, C., 2007, 'Tourism as a tool for poverty alleviation: A critical analysis of "Pro-poor tourism" and implications for sustainability', Current Issues in Tourism 10(2\&3), 144-165. http://dx.doi.org/10.2167/cit303

Cingano, F., 2014, Trends in income inequality and its impact on economic growth, OECD Social, Employment and Migration Working Papers, no. 163, OECD Publishing, Paris, France. 
Clark, H., 2013, 'Foreword', in UNDP, Humanity divided: Confronting inequality in developing countries, pp. XI-XII, United Nations Development Programme, New York.

Cohen, E. \& Cohen, S.A., 2012, 'Current sociological theories and issues in tourism', Annals of Tourism Research 39(4), 2177-2202. http://dx.doi.org/10.1016/j. annals.2012.07.009

Cole, S. \& Morgan, N., 2010, 'Introduction: Tourism and inequalities', in S. Cole \& N. Morgan (eds.), Tourism and inequality: Problems and prospects, pp. xv-xxiii, CABI, Oxford.

De Kadt, E., 1979, Tourism: Passport to development, Oxford University Press, Oxford.

Dhiradityakul, K. \& Hummel, J., 2013, 'Community based tourism in ASEAN: An overview per country', in J. Hummel, H. de Jong \& K. Dhiradityakul (eds.), Innovating CBT in ASEAN: Current directions and new horizons, pp. 5-33, Thailand Innovating CBT in ASEAN: Current directions and
Community Based Tourism Institute, Chiang Mai.

Duffy, R., 2014, 'Interactive elephants: Nature, tourism and neoliberalism', Annals of Tourism Research 44, 88-101. http://dx.doi.org/10.1016/j.annals.2013.09.003

Ellis, S. \& Sheridan, L., 2014, 'The role of resident perceptions in achieving effective community-based tourism for least developed countries', Anatolia - An International Journal of Tourism and Hospitality Research, viewed 6 March 2015, from http://dx.doi.org/10.1080/13032917.2014.939202

Flacke-Neudorfer, C., Burns, P. \& Novelli, M., 2008, 'Actors or victims? Actor oriented perspectives on new forms of tourism', Tourism Development: Growths, Myths, and Inequalities. pp 239-258. CABI, Wallingford, UK.

Fletcher, R., 2011, 'Sustaining tourism, sustaining capitalism? The tourism industry's role in global capitalist expansion', Tourism Geographies 13(3), 443-461. http:// dx.doi.org/10.1080/14616688.2011.570372

Gartner, C. \& Cukier, J., 2012, 'Is tourism employment a sufficient mechanism for poverty reduction? A case study from Nkhata Bay, Malawi', Current Issues in Tourism 15(6), 545-562. http://dx.doi.org/10.1080/13683500.2011.629719

Giampiccoli, A., 2007, 'Hegemony, globalization and tourism policies in developing countries', in P.M. Burns \& M. Novelli (eds.), Tourism and politics. Global framework and local realities, pp. 175-191, Pergamon, Oxford.

Giampiccoli, A., 2015, 'Community-based tourism: Origins and present trends', African Journal for Physical, Health Education, Recreation and Dance 21(2), 675-687.

Giampiccoli, A., Jugmohan, S. \& Mtapuri, O., 2015, 'Community-based tourism in rich and poor countries: Towards a framework for comparison', African Journal for Physical, Health Education, Recreation and Dance 21(4:1), 1200-1216.

Giampiccoli, A. \& Mtapuri, O., 2012, 'Community-based tourism: An exploration of the concept(s) from a political perspective', Tourism Review International 16(1), 29-43. http://dx.doi.org/10.3727/154427212X13431568321500

Giampiccoli, A. \& Mtapuri, O., 2015, 'Between theory and practice: A conceptualization of community based tourism and community participation', Loyola Journal of of community based tourism
Social Sciences XXIX(1), 27-52.

Giampiccoli, A., Saayman, M. \& Jugmohan, S., 2014, 'Developing community-based tourism in South Africa: Addressing the missing link', African Journal for Physical, Health Education, Recreation and Dance 20(3:2), 1139-1161.

Government of Barbados, 2012, Green paper on the sustainable development of tourism in Barbados: A policy framework, viewed 5 November 2015, from http:// www.bhta.org/images/Download/GreenPaper.pdf

Hamzah, A. \& Khalifah, Z., 2009, Handbook on community based tourism: How to develop and sustain CBT, Asia-Pacific Economic Cooperation Secretariat, Kuala Lumpur.

Harvey, D., 2014, Seventeen contradictions and the end of capitalism, Profile Books, London.

Higgins-Desbiolles, F., 2008, 'Justice tourism and alternative globalisation', Journal of Sustainable Tourism 16(3),345-364.http://dx.doi.org/10.1080/09669580802154132

Hunter Wade, R., 2004, 'Is globalization reducing poverty and inequality?' World Development 32(4), 567-589. http://dx.doi.org/10.1016/j.worlddev.2003.10.007

Kayat, K., Ramli, R., Mat-Kasim, M. \& Abdul-Razak, R., 2015, 'Community-based rura tourism as a sustainable development alternative: An analysis with special reference to the community-based rural homestay programmes in Malaysia', in S.M. Radzi, N. Sumarjan, C.T. Chick, M.S.M. Zahari, Z. Mohi, M.F.S. Bakhtiar \& F.I Anuar (eds.), Theory and practice in hospitality and tourism research, $\mathrm{pp}$. $223-227$, CRC Press, Boca Raton.

Kinyondo, A. \& Pelizzo, R., 2015, 'Tourism, development and inequality: The case of Tanzania', Poverty \& Public Policy 7(1), 64-79. http://dx.doi.org/10.1002/pop4.92

Kiss, A., 2004, 'Is community-based ecotourism a good use of biodiversity conservation funds?' Trends in Ecology \& Evolution 19(5), 232-237. http://dx.doi.org/10.1016/j. tree.2004.03.010.

Kontogeorgopoulos, N., Churyen, A. \& Duangsaeng, V., 2014, 'Success factors in community-based tourism in Thailand: The role of luck, external support, and local leadership', Tourism Planning and Development 11(1), 106-124. http:// dx.doi.org/10.1080/21568316.2013.852991

KwaZulu-Natal Department of Economic Development (KZNDED), (n.d.), Communitybased tourism strategy, viewed 7 October 2013, from http://www.kznded.gov.za/ Portals/0/-Community\%20Based\%20Tourism\%20Strategy.pdf

Lefebvre, H., 2002, The production of space, Blackwell, Oxford.

Loizos Christou, D.R., 2012, 'Is it possible to combine mass tourism with alternative forms of tourism: The case of Spain, Greece, Slovenia and Croatia', Journal of Business Administration Online, viewed 2 November 2015, from http://www.atu. edu/jbao/spring2012/is_it_possible_to_combine.pdf

López-Guzmán, T., Sánchez-Cañizares, S. \& Pavón, V., 2011, 'Community-based tourism in developing countries: A case study', Tourismos: An International Multidisciplinary Journal of Tourism 6(1), 69-84.
Maharajh, R., 2011, 'The green economy, poverty and the global inequality', working paper for the International Workshop Biocivilization for the Sustainability of Life and the Planet, run-up to Rio+20 Conference, Rio de Janeiro, 9-12 August, viewed 4 November 2015, from http://www.ritimo.org/IMG/pdf/Green_economy.pdf

Mayaka, M.A., Croy, G. \& Mayson, S., 2012, 'Community-based tourism: Common conceptualistion or disagreement?', in CAUTHE The new golden age of tourism and hospitality; Book 2, 22nd Annual Conference, La Trobe University, Melbourne, 6-9 February, p. 397.

McClendon, R., 2014, New Orleans tourism industry booms but income inequality remains entrenched, viewed 2 November 2015, from http://www.nola.com/ politics/index.ssf/2014/10/new_orleans_tourism_industry_b.html

Ministry of Environment and Tourism (MET), 1995, Promotion of community based tourism, Ministry of Environment and Tourism, Namibia.

Ministry of Hotels and Tourism (MHT), 2013, Policy on community involvement in tourism (CIT), Ministry of Hotels and Tourism, Myanmar.

Ministry of Tourism and Entertainment (MTE), 2014, Towards a national community tourism policy \& strategy: Green paper no. 2/14, Ministry of Tourism and Entertainment, Kingston.

Moscardo, G., 2008, 'Building community capacity for tourism development: Conclusion', in G. Moscardo (ed.), Building community capacity for tourism Conclusion', in G. Moscardo (ed.), Building community
development, pp. 172-179, CAB International, Wallingford.

Mowforth, M., Charlton, C. \& Munt, I., 2008, Tourism and responsibility: Perspectives from Latin America and the Caribbean, Routledge, London.

Mtapuri, O. \& Giampiccoli, A., 2013, 'Interrogating the role of the state and nonstate actors in community-based tourism ventures: Toward a model for spreading the benefits to the wider community', South African Geographical Journal 95(1), 1-15. http://dx.doi.org/10.1080/03736245.2013.805078

Mtapuri, O., Giampiccoli, A. \& Jugmohan, S., 2015, 'Community-based tourism affinity index: A visitor's approach', African Journal of Hospitality, Tourism and Leisure 4(2), 1-13.

Ndlovu, J., Nyakunu, E. \& Auala, S., 2011, 'Community based tourism in Twyfelfontein conservancy: Exploring local community's involvement', International Journal of Hospitality \& Tourism Systems 4(2), 38-46.

Ndlovu, N. \& Rogerson, C.M., 2003, 'Rural local economic development through community-based tourism: The Mehloding hiking and horse trail, Eastern Cape, South Africa', Africa Insight 33(1/2), 124-129.

Neth, B., Ol Rith, S. \& Knerr B., 2008, 'Global environmental governance and politics of ecotourism: Case study of Cambodia', paper presented at 12th EADI General Conference Gobal Governance for Sustainable Development, Geneva 24-28 June, pp. 2-14, viewed 2 December 2015, from http://www.eadi.org/ typo3/fileadmin/Documents/Events/General Conference/2008/paper baromey_et_al.pdf

Pleumaron, A., 2002, 'Community-based ecotourism: Miracle or menace?', paper presented at the IYE Regional Conference on Community-Based Ecotourism in Southeast Asia, Chiang Mai, 3-7th March.

Pleumaron, A., 2003, 'Our world is not for sale! The disturbing implications of privatization in the tourism trade', paper presented at the International Seminar on Tourism: Unfair Practices - Equitable Options, Hannover, 8-9th December, viewed 5 November 2015, from http://www.twn.my/title2/resurgence/207-208/ cover1.doc

Pleumaron, A., n.d., Campaign on corporate power in tourism (COCPIT), viewed 5 November 2015, from http://www.twn.my/title/eco1.htm

Pulido-Fernández, J.I. \& López-Sánchez, Y., 2011, 'Tourism: Analysis of a global phenomenon from a perspective of sustainability', in P. Pachura (ed.), The systemic dimension of globalization, pp. 267-288, viewed 28 October 2015, from http:// cdn.intechopen.com/pdfs-wm/17426.pdf

Roslinda, E.M., 2013, 'Integrating innovation, quality and standardization in CBT in the Philippines: Three examples from Bohol Province', in J. Hummel, H. de Jong \& K. Dhiradityakul (eds.), Innovating CBT in ASEAN: Current directions and new horizons, pp. 57-64, Thailand Community Based Tourism Institute, Chiang Mai.

Saayman, M. \& Giampiccoli, A., 2016, 'Community-based and pro-poor tourism: Initial assessment of their relation to community development', European Journal of Tourism Research 12, pp 145-190 (Spring 2016).

Saayman, M., Rossouw, R. \& Krugell, W., 2012, 'The impact of tourism on poverty in South Africa', Development Southern Africa 29(3), 462-487. http://dx.doi.org/10. 1080/0376835X.2012.706041

Schilcher, D., 2007, 'Growth versus equity: The continuum of pro-tourism and neoliberal governance', in M. Hall (ed.), Pro-poor tourism: Who benefits? neoliberal governance', in $\mathrm{M}$. Hall (ed.), Pro-poor tourism: Who benefits?
Perspective on tourism and poverty reduction, pp. 56-83, Channel View Perspective on tourism
Publications, Clevedon.

Scott, D. \& Gössling, S., 2015, 'What could the next 40 years hold for global tourism?' Tourism Recreation Research 40(3), 269-285. http://dx.doi.org/10.1080/0250828 Tourism Recreation
1.2015.1075739

Suansri, P., 2013, 'Introduction', in J. Hummel, H. de Jong \& K. Dhiradityakul (eds.), Innovating CBT in ASEAN: Current directions and new horizons, pp. 1-4, Thailand Community Based Tourism Institute, Chaing Mai.

Suansri, P., Yeejaw-haw, S. \& Richards, P., 2013, Community-based tourism standard handbook, Thailand Community-Based Tourism Institute, Payap University, Chaing Mai.

Suhandi, A.S. \& Simatupang, W., 2013, 'Community based tourism standard in Indonesia: Between needs and challenges', in J. Hummel, H. de Jong \& $\mathrm{K}$. Dhiradityakul (eds.), Innovating CBT in ASEAN: Current directions and new Horizons, pp. 47-56, Thailand Community Based Tourism Institute, Chiang Mai.

UN, 2013, Inequality matters: Report of the world social situation, United Nations, New York. 
United Nations Development Programme (UNDP), 2013. Humanity divided: Confronting inequality in developing countries, United Nations Development Confronting inequality
Programme, New York.

United Nations Economic Scientific and Cultural Organisation (UNESCO), 2014, Community-based tourism development in Triem Tay Village, viewed 5 November 2015, from http://cbt-i.org/cbtstandardforum/download/InnovatingCBTinASEAN_ CurrentDirectionsAndFutureHorizons_Eng.pdf

United Nations World Tourism Organisation (UNWTO)a, n.d., Why tourism?, viewed 28 October 2015, from http://www2.unwto.org/content/why-tourism
United Nations World Tourism Organisation (UNWTO)b, n.d., Rural and communitybased tourism, viewed 28 October 2015, from http://sdt.unwto.org/en/content/ rural-and-community-based-tourism

World Travel and Tourism Council (WTTC), 2013, Tourism for tomorrow: Position paper, viewed 28 October 2015, from https://www.wttc.org/-/media/files/ reports/mission/tourism $\% 20$ for\%20tomorrow $\% 20$ - $\% 20$ final_rgb.pdf

Zajda, J., 2011, 'Globalisation and schooling: Equity and access issues', Cultural Studies of Science Education 6, 143-152. http://dx.doi.org/10.1007/s11422-0109309-z 